\title{
Binding of Benanomicin A to Fungal Cells in Reference to its Fungicidal Action
}

\author{
Maki Watanabe, Shuichi Gomi*, Hiroyoshi Tohyama, Keiko Ohtsuka, Seiji Shibahara, \\ Shigeharu InOuYe ${ }^{\dagger}$, Hidemitsu Kobayashi ${ }^{a}$, Shigeo Suzuki ${ }^{a}$, Shinichi Kondo ${ }^{b}$, \\ TOMIO TAKEUCHI ${ }^{b}$ and HideYo YAMAGUCHI ${ }^{\mathrm{c}}$ \\ Pharmaceutical Research Center, Meiji Seika Kaisha, Ltd., \\ Morooka, Kohoku-ku, Yokohama 222, Japan \\ ${ }^{a}$ Tohoku College of Pharmacy, \\ Sendai 981, Japan \\ ${ }^{b}$ Institute of Microbial Chemistry, \\ Kamiosaki, Shinagawa-ku, Tokyo 141, Japan \\ ${ }^{c}$ Research Center for Medical Mycology, Teikyo University School of Medicine, \\ Hachioji, Tokyo 192-03, Japan
}

(Received for publication November 30, 1996)

\begin{abstract}
An antifungal antibiotic, benanomicin $\mathrm{A}$, binds in the presence of $\mathrm{Ca}^{2+}$ to susceptible fungi and some bacieria, but not to antibiotic-resistant bacteria and mammalian cells. With the susceptible yeast Saccharomyces cerevisiae, benanomicin A binds similarly to whole cells and to protoplasts. Studies using benanomicin A and three structurally related derivatives suggested that a carboxylic acid in the D-alanine moiety and a sugar moiety in the benanomicin A molecule are essential for both binding and antifungal activities against growing $S$. cerevisiae. An amino substituent on the sugar moiety can be replaced with a hydroxyl group without the loss of activities. Benanomicin A binds to various yeast mannans which differ in glycosidic linkages. These results indicate that binding of benanomicin A to the mannan portion of fungal cells is essential for exertion of the antifungal activity.
\end{abstract}

Benanomicin A produced by Actinomadura sporax ${ }^{1,2)}$ is a red-colored antibiotic consisting of benzo[a]naphthacenequinone, D-alanine and a disaccharide (Fig. 1). ${ }^{3)}$ Previous studies demonstrated that benanomicin A inhibits growth of a wide range of pathogenic fungi including Candida spp., Aspergillus spp. and Cryptococcus neoformans, that parenteral doses of the antibiotic protected mice against a lethal infection with these fungi, and that it was well tolerated by mice and other experimental animals. ${ }^{4,5}$

At an early stage of our investigation, it was observed that a red-colored ring was formed in the marginal region of inhibitory zones on agar medium implanted with a test fungus when an agar diffusion assay with the antibiotic was performed. In addition, fungal cells aggregated and showed a red color when they were treated with the antibiotic in liquid medium. These findings strongly suggested that substantial amounts of benanomicin $\mathrm{A}$ are bound to fungal cells when the antibiotic and cells are incubated together.

The present study was undertaken to get informa- tion on the binding property of benanomicin A to yeast cells in order to further elucidate the mode of its antifungal action. For this purpose the benanomicin Arelated compounds benanomicin $B$, its methyl ester and benanomicinone (Fig. 1), as well as several different mannan preparations, were used to define the molecular basis of the binding activity. Preliminary results were reported elsewhere. ${ }^{6,7)}$

\section{Materials and Methods}

Benanomicins, Related Compounds, Mannan Preparations and Other Chemicals

Benanomicins $\mathrm{A}$ and $\mathrm{B}$, benanomicin $\mathrm{B}$ methyl ester and benanomicinone were prepared as previously reported. ${ }^{3,8)}$ Chemically modified mannans containing various glycosidic linkages were prepared from the mannans of the following fungal species by $\mathrm{NaBH}_{4}$ reduction under alkaline conditions according to the literature. $^{9 \sim 11)}$ Modified mannan 1A, containing $\alpha-1,2-$ and $\alpha$-1,3-linkages, was obtained from Saccharomyces cerevisiae X2180-1A; modified mannan 1A-5, containing $\alpha-1,6$-linkage, from $S$. cerevisiae X2180-1A-5; modified

+ Present address: Research Center for Pathogenic Fungi and Microbial Toxicoses, Chiba University, 1-8-1 Inohana, Chuo-ku, Chiba 260, Japan. 
Fig. 1. Structures of benanomicins A and the related compounds.

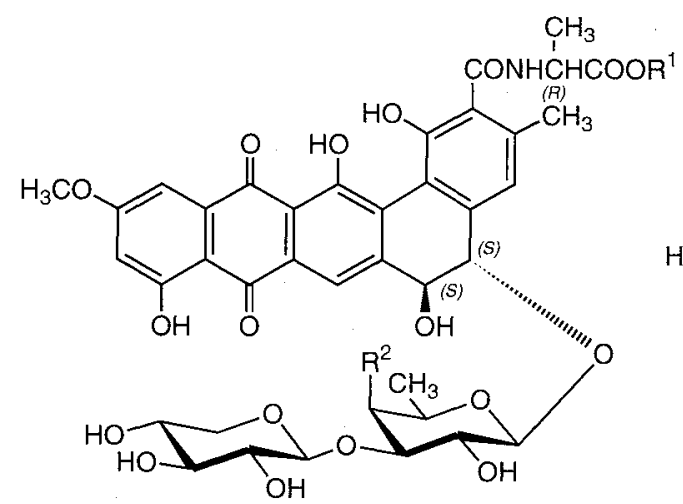

\begin{tabular}{lll}
\hline & $\mathbf{R}^{1}$ & $\mathbf{R}^{2}$ \\
\hline Benanomicin A sodium salt & $\mathrm{Na}$ & $\mathrm{OH}$ \\
Benanomicin B sodium salt & $\mathrm{Na}$ & $\mathrm{NH}_{2}$ \\
Benanomicin B methyl ester & $\mathrm{CH}_{3}$ & $\mathrm{NH}_{3}{ }^{+} \mathrm{Cl}^{-}$ \\
\hline
\end{tabular}<smiles>COc1cc(O)c2c(c1)C(=O)c1c(cc3c(c1O)-c1c(cc(C)c(C(N)=O)c1O)[C@H](O)[C@H]3O)C2=O</smiles>

Benanomicinone sodium salt mannan $\mathrm{P}$, containing $\beta$-1,2-linkage, from Pichia pastoris IFO0948; modified mannan A from Candida albicans NIH A-207 (serotype A). The modified mannans contained $96.0 \sim 99.5 \%$ carbohydrate content (determined by the phenol-sulfuric acid method), $0.1 \sim 0.2 \%$ protein (determined by the Folin method), $0.08 \sim 0.97 \%$ phosphate (determined by the Ams-Dubin method) and $0.7 \mathrm{ppm}$ calcium. The Saccharomyces mannan used in the experiments of gel filtration was that derived from S. cerevisiae (Sigma M 7504, Sigma Chemical Company, St. Louis). EGTA (Ethylene glycol-bis $(\beta$-aminoethyl ether) $N, N, N^{\prime}, N^{\prime}$-tetraacetic acid), $\mathrm{CaCl}_{2}$ and other chemicals were commercial products from Wako Chemicals (Tokyo). Concanavalin A and FITC-labeled concanavalin A were from Sigma.

\section{Spectrophotometric Analyses}

UV and visible spectra were determined in aqueous solution with a Hitachi UV spectrometer. Optical rotations were determined with a JAS DIP-360 digital polarimeter using a $1-\mathrm{cm}$ cell. Aqueous solutions of $0.05 \%$ benanomicin $\mathrm{A}$ and $0.20 \sim 0.60 \%$ glycan or sugar were used. Flow cytometry was conducted using a FAC Star, Benton Dickinson, California, U.S.A.

\section{Fungal, Bacterial and Tumor Cell Strains}

S. cerevisiae X2180-1A was kindly supplied by Dr. Y. OsumI, University of Tokyo. All other fungal strains including Candida albicans Y-2, Cryptococcus neoformans IMC F-10 and Aspergillus fumigatus TIMM1775 and two bacterial strains, Corynebacterium xerosis NCTC9775 and Escherichia coli NIHJ were from culture collections at the Pharmaceutical Research Center, Meiji Seika Kaisha, Ltd. or the Research Center for Medical Mycology, Teikyo University. P388 leukemia cells and NRK (normal rat kidney) cells were cell lines stocked in the Pharmaceutical Research Center, Meiji Seika Kaisha, Ltd.

\section{Preparation of Saccharomyces Protoplasts}

The washed cells of $S$. cerevisiae X2180-1A were suspended in $1 / 15 \mathrm{M}$ sodium phosphate buffer containing $20 \mathrm{~mm}$ EDTA, $1 \mathrm{~mm}$ mercaptoethanol and $1.2 \mathrm{M}$ sorbitol as an osmotic stabilizer to give a cell suspension at a concentration of $1 \times 10^{8} \mathrm{cells} / \mathrm{ml}$. The cell suspension was mixed with Zymolyase 100T (Seikagaku Kogyo Co., Tokyo) suspended in the same buffer at a final concentration of $100 \mu \mathrm{g} / \mathrm{ml}$. The mixture was incubated at $27^{\circ} \mathrm{C}$ for 30 minutes with gentle shaking. Completion of protoplast formation was confirmed under a microscope by the observation that almost all cells burst after dilution with water. Protoplasts thus prepared were collected by centrifugation $(1,500 \mathrm{rpm}, 5$ minutes $)$, washed three times with $1 / 15 \mathrm{M}$ sodium phosphate buffer containing $1.2 \mathrm{M}$ sorbitol, and then resuspended in an appropriate medium for use.

Determination of Mannose Content in Whole Cells and Protoplasts of $S$. cerevisiae

The washed cells ( $10^{8}$ cells) of $S$. cerevisiae X2180-1A or its protoplasts were mixed with $1 \mathrm{ml}$ of $1 \mathrm{~N}$ sulfuric acid, heated at $100^{\circ} \mathrm{C}$ for 5 hours, and neutralized with barium carbonate. The mixture was centrifuged, and the supernatant and washings were combined, concentrated, and subjected to HPLC analysis under the following conditions: column, Shim-pack ISA-07/S2504 (4.0 × 250 $\mathrm{mm})$; mobile phase, gradient of $0.1 \mathrm{M}$ borate buffer $(\mathrm{pH}$ 8.0 ) and $0.4 \mathrm{M}$ borate buffer ( $\mathrm{pH} 9.0$ ); flow rate, $0.7 \mathrm{ml} /$ minutes; temperature, $65^{\circ} \mathrm{C}$; detection, post-column fluorescence using $1 \%$ arginine-boric acid. ${ }^{12)}$ 
Determination of Benanomicin A Binding to Fungal Cells

The fungal cultures were grown at $30^{\circ} \mathrm{C}$ for 48 hours (24hours in Aspergillus sp.) in YPG medium (yeast extract $0.5 \%$, Polypeptone $1.0 \%$ and glucose $2.0 \%$ ). The bacterial cultures were grown at $37^{\circ} \mathrm{C}$ for 24 hours in Nutrient broth (Difco). The fungal or bacterial cells were harvested by centrifugation at 3,000 rpm for 5 minutes, and washed three times with sterilized water or saline.

The washed microbial cells were suspended in DULBECCO's phosphate buffered saline (pH 7.5, DPBS, Sigma) supplemented with $1 \mathrm{mM} \mathrm{CaCl}_{2}$ and adjusted to $2 \times 10^{7}$ cells per $\mathrm{ml}$ by counting with a hemocytometer. To $1 \mathrm{ml}$ of the cell suspension was added an equal volume of aqueous solution of benanomicin A (200 $\mu \mathrm{g} / \mathrm{ml}$ ). After stirring for 5 minutes, the mixture was incubated statically at $27^{\circ} \mathrm{C}$ for fungi or $37^{\circ} \mathrm{C}$ for bacteria for 30 minutes, and centrifuged at $3,000 \mathrm{rpm}$ for 3 minutes. The sedimented cells were washed by centrifugation three times with DPBS, and the antibiotic bound to the cells was extracted with $2 \mathrm{ml}$ of dimethyl sulfoxide (DMSO) by stirring for 5 minutes, then recovered from the supernatant after centrifugation at $3,000 \mathrm{rpm}$ for 3 minutes. The concentration of the antibiotic in the supernatant was determined by measuring the optical density at $490 \mathrm{~nm}$ with a UV/visible spectrophotometer, and the amount of the antibiotic bound to $10^{7}$ cells was calculated. Viable yeast cells were counted using a conventional colony count technique on YPG agar plate. Aspergillus fumigatus conidia were collected on a GF/c filter, and binding amount was expressed on a weight basis owing to the difficulty of cell counting.

Determination of Benanomicin A Binding to Tumor Cells, NRK cells and Erythrocytes

P388 leukemia cells were grown at $37^{\circ} \mathrm{C}$ in RPMI- 1640 medium (Nissui) supplemented with $10 \%$ fetal calf serum. The cells were collected by centrifugation at $1,000 \mathrm{rpm}$ for 5 minutes, washed with the same warmed medium, and resuspended in DPBS containing $1 \mathrm{~mm}$ $\mathrm{CaCl}_{2}$. NRK cells were grown at $37^{\circ} \mathrm{C}$ in Dulbecco's modified Eagle medium (DMEM, Nissui) containing $50 \%$ fetal calf serum. Experimental cell suspension of P388 leukemia cells and NRK cells at a concentration of $1.6 \times 10^{6}$ and $2 \times 10^{6} \mathrm{cells} / \mathrm{ml}$, respectively, was inoculated at a volume of $1 \mathrm{ml}$ into each plastic dish (Falcon 3001). The cells adhering to dishes were washed with DMEM, and suspended in DPBS containing $1 \mathrm{mM}$ $\mathrm{CaCl}_{2}$. Murine erythrocytes were obtained from blood taken from descending cava of male $\mathrm{Crj}$ : $\mathrm{CDl}$ (ICR) mice under anesthesia, and washed with DPBS by centrifugation at $3,000 \mathrm{rpm}$ for 5 minutes. The sedimented erythrocytes $(0.4 \mathrm{ml})$ were finally suspended in DPBS $(0.6 \mathrm{ml})$ containing $1 \mathrm{mM} \mathrm{CaCl}$ at a cell concentration of $1 \times 10^{6} \mathrm{cells} / \mathrm{ml}$.

Benanomicin A was added to an experimental cell suspension at a final drug concentration of $100 \mu \mathrm{g} / \mathrm{ml}$, and the mixture was incubated at $37^{\circ} \mathrm{C}$ for 30 minutes.
After centrifugation at $3,000 \mathrm{rpm}$ for 5 minutes, the supernatant was removed, and extracted with $200 \mu$ l of DMSO. The determination of bound benanomicin A in the extract was made using the same method as used for experiments with microbial cells as above mentioned.

Determination of Antimicrobial and Cytotoxic Activities

Antimicrobial activity of benanomicin A was determined by the agar dilution method on Kimmig agar for fungi, and nutrient agar (Difco) for Escherichia coli, or by the broth dilution method in a liquid medium consisting of Bactopeptone $1.0 \%$, beef extract $0.3 \%$ and $\mathrm{NaCl} 3.0 \%$ for Corynebacterium sp. The activity was expressed as the minimum growth-inhibitory concentration (MIC).

Cytotoxicity of benanomicin A against P388 leukemia cells and NRK cells was determined by the staining technique. P388 leukemia cells were suspended in RPMI- 1640 containing $10 \%$ fetal calf serum and NRK cells in DMEM containing 5\% fetal calf serum at a concentration of $1 \times 10^{6}$ and $2 \times 10^{6} \mathrm{cells} / \mathrm{ml}$, respectively. The cell suspension in a volume of $4 \mathrm{ml}$ was incubated in the presence of benanomicin $\mathrm{A}$ at $37^{\circ} \mathrm{C}$ for 3 days in $5 \% \mathrm{CO}_{2}$ atmosphere. Number of surviving cells was measured by staining with 3-(4,5-dimethyl-thiazole-2yl)-2,5-diphenyltetrazolium bromide. Those drug concentrations killing $50 \%$ of the tested cells were defined as $\mathrm{IC}_{50}$ values.

Recovery of Benanomicin A from Preloaded Fungal Cells

C. albicans Y-2 cells $\left(4.4 \times 10^{7}\right.$ cells $)$ were mixed with $100 \mu \mathrm{g}$ of benanomicin A in a volume of $1 \mathrm{ml}$, and incubated for 30 minutes at room temperature. After centrifugation at 3,000 rpm for 5 minutes, the yeast cells sedimented were resuspended in $1 \mathrm{ml}$ of the indicated solvent and incubated at $25^{\circ} \mathrm{C}$ for 5 minutes to extract the benanomicin A bound to the cells. The extract was subjected to HPLC analysis to determine cell-bound benanomicin $\mathrm{A}$ under the following conditions: Precolumn, Cosmosil 10 $\mathrm{C}_{18} 4.6 \times 50 \mathrm{~mm}$; column, Cosmosil $5 \mathrm{C}_{18} 4.6 \times 150 \mathrm{~mm}$; mobile phase, $0.5 \% \mathrm{KH}_{2} \mathrm{PO}_{4}{ }^{-}$ $\mathrm{CH}_{3} \mathrm{OH}$ (1:1); flow rate, $1 \mathrm{ml} /$ minute; temperature, $40^{\circ} \mathrm{C}$ and $\mathrm{UV}$ detection at $280 \mathrm{~nm}$.

Measurement of Lytic Activity against Fungal Protoplasts

Protoplasts of S. cerevisiae X2180-1A were suspended in YNB-S-PB (YNB supplemented with $1.2 \mathrm{M}$ sorbitol and $1 / 15 \mathrm{~m}$ sodium phosphate buffer, $\mathrm{pH}$ 7.0) supplemented with $1 \%$ glucose, and adjusted to a concentration of $1 \times 10^{6} \mathrm{cells} / \mathrm{ml}$. The protoplast suspension was dispersed in a volume of $180 \mu \mathrm{l}$ into each well of flat bottom microtiter plates ( 96 wells) which received $20 \mu \mathrm{l}$ of a solution of benanomicin $\mathrm{A}$ or another test drug. Tween 80 was added at a concentration of $1 \%$ in the experiments when necessary. The plates were incubated 
at $37^{\circ} \mathrm{C}$ and the optical density of each well was read at $620 \mathrm{~nm}$ using an automated reader (Titertek Multiskan MC, Labsystem and Flow Laboratory). When $10^{6}$ protoplasts were applied, a decrease of 0.1 optical density was given by lysis of approximately $10^{3}$ protoplasts.

Determination of Hemolysis of Murine Erythrocytes The experimental procedure was similar to that described by TANIGUCHI et al. ${ }^{13)}$ To a $1 \%$ suspension $(5 \mathrm{ml})$ of murine erythrocytes in HANK's solution ( $\mathrm{pH} 7.5$ ) in test tubes was added an aqueous solution of benanomicin A $(5 \mu \mathrm{l})$. After standing at room temperature for 30 minutes, the test tubes were shaken at a rate of 200 strokes per minutes for $5 ; 10,20,30$ and 60 minutes. After centrifugation at $3,000 \mathrm{rpm}$, hemoglobin in the supernatant was measured at $540 \mathrm{~nm}$ with a UV/visible spectrophotometer. The rate of hemolysis was calculated using a control value without Folin as $100 \%$.

Gel Filtration Analysis of Interaction of Benanomicin A with Saccharomyces Mannan

Ten $\mathrm{mg}$ of Saccharomyces mannan (Sigma) was dissolved in $200 \mu \mathrm{l}$ of distilled water. One hundred $\mu \mathrm{l}$ of aqueous solution of benanomicin A $(8 \mathrm{mg} / \mathrm{ml})$ was mixed with $200 \mu \mathrm{l}$ of aqueous solution of Saccharomyces mannan. After incubation at room temperature for 5 minutes, the reaction mixture was passed through a column of Sephadex G-50 (15 ml), and developed with water. Effluent was collected in $1-\mathrm{ml}$ fractions. With each fraction, optical density at $490 \mathrm{~nm}$ and antifungal activity against $C$. albicans cells were determined.

To test the effect of $\mathrm{Ca}^{2+}$ on benanomicin A-Saccharomyces mannan interaction, the reaction mixture containing $400 \mu \mathrm{g}$ of benanomicin A and $5 \mathrm{mg}$ of Saccharomyces mannan was supplemented with $20 \mu \mathrm{g}$ of $\mathrm{CaCl}_{2}$, adjusted to a final volume of $350 \mu \mathrm{l}$, and passed through a Sephadex column.

\section{Results}

Requirement of $\mathrm{Ca}^{2+}$ for Binding of

Benanomicin A to Fungal Cells

Table 1 shows effects of $\mathrm{CaCl}_{2}$ and EGTA on the binding of benanomicin $\mathrm{A}$ to the susceptible yeast, $C$. albicans. Addition of $\mathrm{Ca}^{2+}$ significantly stimulated the bindings of antibiotic to cells. The concurrent addition of EGTA with $\mathrm{Ca}^{2+}$ reduced the binding of benanomicin A, to near baseline.

These results suggested that $\mathrm{Ca}^{2+}$ is required for antibiotic binding. Accordingly, all of the following experiments were carried out using a medium containing $\mathrm{Ca}^{2+}$ unless otherwise stated.

\section{Binding of Benanomicin A to Different Microbial Cells}

Table 2 shows the binding of benanomicin $A$ to four different species of fungi and two species of bacteria. Benanomicin A bound in a range of $7.5 \sim 25 \mu \mathrm{g} / 10^{7}$ cells to all the antibiotic susceptible species of fungi (MIC, $1.56 \sim 12.5 \mu \mathrm{g} / \mathrm{ml}$ ). Benanomicin $\mathrm{A}$ also bound to one antibiotic susceptible bacterium, Corynebacterium xerosis (MIC, $6.25 \mu \mathrm{g} / \mathrm{ml}$ ), but did not bind to benanomicin resistant $E$. coli strain (MIC, $100 \mu \mathrm{g} / \mathrm{ml}$ ). No substantial binding of benanomicin A was observed with any of mammalian cells tested, viz., P388 leukemia cells, NRK cells or murine erythrocytes. Furthermore no cytotoxicity or hemolysis was observed with these cells and erythrocytes at $100 \mu \mathrm{g} / \mathrm{ml}$.

In order to investigate the strength of benanomicin A binding to $C$. albicans, various solvents were used to

Table 1. Effect of $\mathrm{CaCl}_{2}$ and EGTA on the binding of benanomicin A to C. albicans ${ }^{\mathrm{a})}$.

\begin{tabular}{|c|c|c|}
\hline \multicolumn{2}{|c|}{ Addition of: } & \multirow{2}{*}{$\begin{array}{c}\text { Amount of } \\
\text { benanomicin A } \\
\text { bound to } 10^{7} \text { cells } \\
(\mu \mathrm{g})\end{array}$} \\
\hline $\begin{array}{c}\mathrm{CaCl}_{2} \\
(\mathrm{mM})\end{array}$ & $\begin{array}{c}\text { EGTA } \\
(\mathrm{mM})\end{array}$ & \\
\hline 0 & 0 & 0.2 \\
\hline 0 & 2 & 0.2 \\
\hline 1 & 0 & 13 \\
\hline 1 & 2 & 1.9 \\
\hline
\end{tabular}

a) Initial concentration of benanomicin A, $100 \mu \mathrm{g} / \mathrm{ml}$. Initial inoculum of $C$. albicans Y-2 suspended in DPBS, $4.4 \times 10^{7}$ $\mathrm{CFU} / \mathrm{ml}$.

Table 2. Ability of benanomicin A to bind to and inhibit several fungi and bacteria.

\begin{tabular}{lcc}
\hline \multicolumn{1}{c}{ Organism } & $\begin{array}{c}\text { Amount of benanomicin A } \\
\text { bound to } 10^{7} \text { cells } \\
(\mu \mathrm{g})\end{array}$ & $\begin{array}{c}\text { Minimum growth inhibitory } \\
\text { concentration of benanomicin A } \\
(\mu \mathrm{g} / \mathrm{ml})\end{array}$ \\
\hline Candida albicans Y-2 & 13 & 6.25 \\
Saccharomyces cerevisiae X2180-1A & 25 & 3.13 \\
Cryptococcus neoformans IMC F-10 & 7.5 & 1.56 \\
Aspergillus fumigatus TIMM1775 & $21^{*}$ & 12.5 \\
Corynebacterium xerosis NCTC9775 & 4.5 & 6.25 \\
Escherichia coli NIHJ & 0.1 & 100 \\
\hline
\end{tabular}

$* \mu \mathrm{g} / \mathrm{mg}$ (dry weight). 
Table 3. Binding and bioactivity of benanomicin A and related compounds to C. albicans and S. cerevisiae.

\begin{tabular}{|c|c|c|c|c|c|c|}
\hline \multirow[b]{2}{*}{ Compound } & \multicolumn{2}{|c|}{ Whole cells of $C$. albicans Y-2 } & \multicolumn{2}{|c|}{ Whole cells of $S$. cerevisiae } & \multicolumn{2}{|c|}{ Protoplasts of $S$. cerevisiae } \\
\hline & $\begin{array}{l}\text { Amount of } \\
\text { benanomicin } \\
\text { A bound } \\
\left(\mu \mathrm{g} / 10^{7} \text { cells) }\right.\end{array}$ & $\begin{array}{l}\text { Susceptibility to } \\
\text { benanomicin A } \\
\qquad(\mu \mathrm{g} / \mathrm{ml})^{*}\end{array}$ & $\begin{array}{l}\text { Amount of } \\
\text { benanomicin } \\
\text { A bound } \\
\left(\mu \mathrm{g} / 10^{7} \text { cells }\right)\end{array}$ & $\begin{array}{l}\text { Susceptibility to } \\
\text { benanomicin A } \\
(\mu \mathrm{g} / \mathrm{ml})^{*}\end{array}$ & $\begin{array}{l}\text { Amount of } \\
\text { benanomicin } \\
\text { A bound } \\
\left(\mu \mathrm{g} / 10^{7} \text { cells }\right)\end{array}$ & $\begin{array}{c}\text { Susceptibility to } \\
\text { benanomicin A } \\
(\%)^{* *}\end{array}$ \\
\hline Benanomicin A & 13 & 6.25 & 25 & 1.56 & 8.0 & 99.9 \\
\hline Benanomicin B & 18 & 12.5 & 30 & 1.56 & 28 & 99.9 \\
\hline Benanomicin B methyl ester & 1 & 100 & 1 & 100 & 0.4 & 0 \\
\hline Benanomicinone & 1 & 100 & 1 & 100 & 0.4 & 0 \\
\hline
\end{tabular}

* Minimum growth inhibitory concentration.

** Decrease in number of intact protoplasts 120 minutes after addition of drug $(50 \mu \mathrm{g} / \mathrm{ml})$ in YNBD-S-PB medium

extract prebound benanomicin A. The recovery of the antibiotic was very low when extracted with acetone $(1.0 \%)$, moderate with water $(14.9 \%), N, N$-dimethylformamide $(37.3 \%)$ or $5 \mathrm{~mm}$ EGTA $(49.5 \%)$, but almost complete with DMSO $(99.0 \%)$. These results suggested that the binding was not irreversible covalent bonding but reversible hydrogen bonding.

Correlation of the Structure of Benanomicin A with Its Binding Ability and Antifungal Activity

Table 3 shows the extent of binding of benanomicin A and related compounds to Candida and Saccharomyces cells and their protoplasts. Benanomicins A and B bound to both whole fungal cells and their protoplasts, in parallel to the growth-inhibitory activity (against the whole cells) and lytic activity (against the protoplasts). Benanomicin A bound to the whole cells of $S$. cerevisiae to a greater extent than to their protoplasts, but benanomicin B, a basic analog of benanomicin A, showed comparable binding to both whole cells and protoplasts. Analysis of the mannan content in the whole cells and protoplasts of $S$. cerevisiae X2180-1A, using the acid hydrolysates of samples, revealed that mannans in the whole cells and protoplasts were 20 and $2.5 \mu \mathrm{g} / 10^{7}$ cells, respectively. A derivative of benanomicin $B$ lacking either an acidic function (benanomicin B methyl ester) or the sugar moiety (benanomicinone) did not bind to nor inhibit $C$. albicans or $S$. cerevisiae.

Protoplast Lytic Activity of Benanomicin A

Figure 2 shows the time-course of lysis of $S$. cerevisiae protoplasts when treated with $20 \mu \mathrm{g} / \mathrm{ml}$ of benanomicin $A$ in YNBD-S-PB, as measured by a decrease in optical density. Concanavalin A which is known to bind to the mannan moiety of yeast cells was used as a reference. Benanomicin A was capable of inducing protoplast lysis, and the extent of this was further increased by the
Fig. 2. Time course of antifungal action of benanomicin A $(20 \mu \mathrm{g} / \mathrm{ml})$ and concanavalin $\mathrm{A}(1,000 \mu \mathrm{g} / \mathrm{ml})$ on protoplast of $S$. cerevisiae $\mathrm{X} 2810-1 \mathrm{~A}$ with or without Tween $80(1 \%)$.

$\mathrm{O}$ : Benanomicin A, $\bullet$ : benanomicin A plus Tween 80 , $\square$ : concanavalin A, $\mathbf{\square}$ : concanavalin A plus Tween 80 .

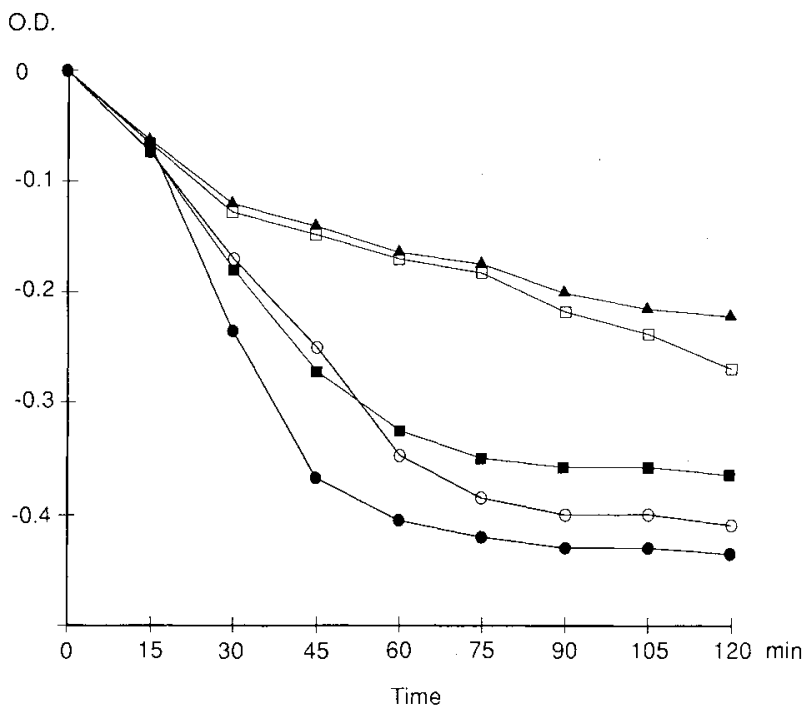

addition of $1 \%$ Tween 80 . Concanavalin $\mathrm{A}$, in contrast, at $1,000 \mu \mathrm{g} / \mathrm{ml}$ induced only slight protoplast lysis which was accelerated in the presence of Tween 80 . One percent Tween 80 alone showed no effect on the protoplast lysis. This indicated that benanomicin $A$, which shows the cytolytic action alone, has a different mechanism of action than concanavalin $\mathrm{A}$ that requires the Tween 80 for lysis.

As measured by flow cytometry, the relative fluorescence intensity of $S$. cerevisiae protoplasts in YNB-SPB treated with FITC-concanavalin A $(1,000 \mu \mathrm{g} / \mathrm{ml})$ for 30 minutes was 311 , and this was decreased to 192 after pretreatment with benanomicin A $(25 \mu \mathrm{g} / \mathrm{ml})$ for 5 minutes. The intensity of the protoplasts treated with 
benanomicin $\mathrm{A}$ alone was 7.6. The decrease in fluorescence of the concanavalin A treated protoplasts following benanomicin A pretreatment suggested competitive binding of two compounds.

\section{Interaction of Benanomicin A with Saccharomyces Mannan}

We examined benanomicin A interaction with Saccharomyces mannan using a gel filtration technique with a column of Sephadex G-50. The elution pattern of an aqueous solution of benanomicin $\mathrm{A}$ showed a single red-colored peak (peak I) in the range of fraction 10 accompanied by a tailing (Fig. 3A). When a mixture of benanomicin $\mathrm{A}$ and yeast mannan at a weight ratio of $1: 12$ was passed through the Sephadex column, an additional red-colored peak (peak II) appeared in the range of fraction 6 (Fig. 3B). Mannan was exclusively recovered from peak II. Fraction 10 (peak I) was active in inhibiting fungal growth, whereas fraction 6 (peak II) showed no activity at all. When the mixture of benanomicin $\mathrm{A}$ and yeast mannan was charged to the column in the presence of $2 \mathrm{mM} \mathrm{Ca}^{2+}$, there occurred an increase in the peak II area with a concomitant decrease in the peak I area (Fig. 3C). This indicated that benanomicin $\mathrm{A}$ bound to yeast mannan, and that in so doing it lost its antifungal activity.

\section{Interaction of Benanomicin A with Chemically Modified Yeast Mannans}

Table 4 shows the interaction of benanomicin A with modified yeast mannans that contain different glycosidic linkages: $\alpha-1,2$ and $\alpha-1,3(1 \mathrm{~A}) ; \alpha-1,6(1 \mathrm{~A}-5)$; and $\beta-1,2$ (P). Utilizing the changes of absorption spectrum and optical rotation, all of these chemically modified mannans when added to an aqueous solution of benanomicin A produced the same spectral change. The absorption
Fig. 3. Gel filtration patterns of benanomicin A - Saccharomyces mannan complexes over Sephadex G-50.

A: Benanomicin A alone, B: benanomicin A plus Saccharomyces mannan $(1: 12 \mathrm{w} / \mathrm{w})$, C: benanomicin $\mathrm{A}$, Saccharomyces mannan plus $\mathrm{CaCl}_{2}(2 \mathrm{mM})$.
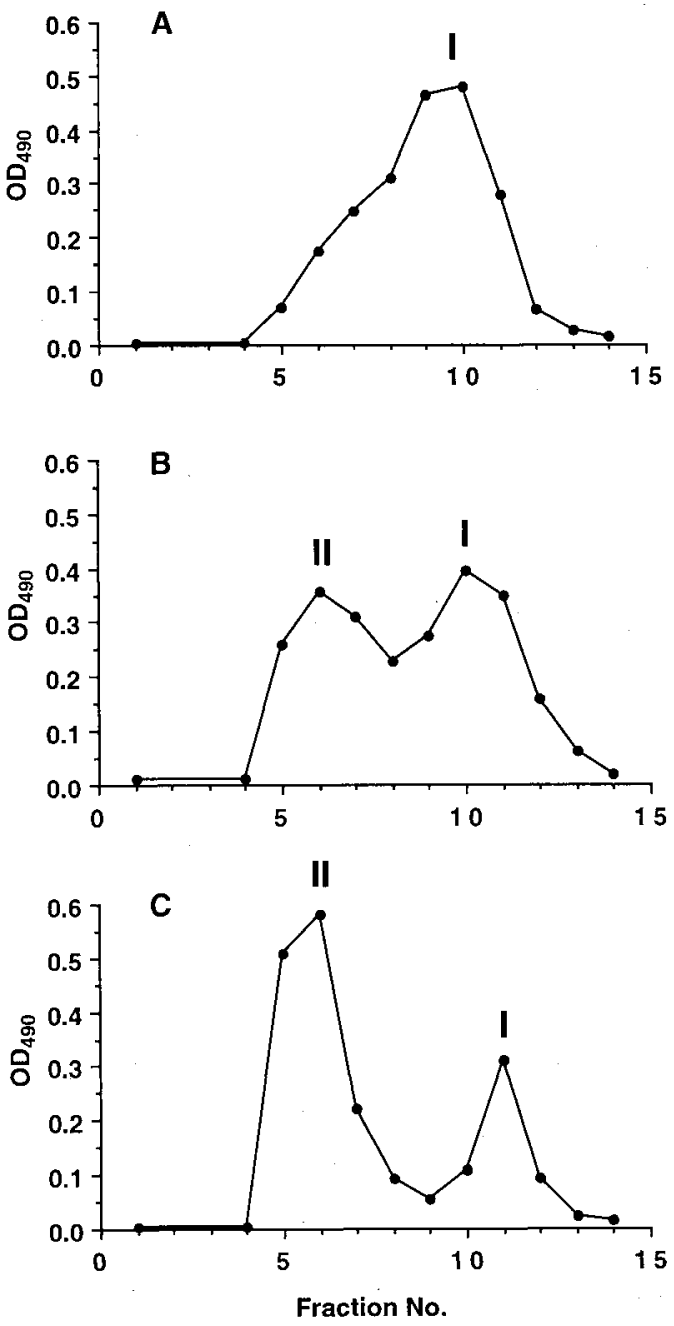

Table 4. Visible and rotational changes due to interaction between benanomicin $\mathrm{A}$ and modified yeast mannans containing various glycosidic linkages and D-mannose and dextran T-40*.

\begin{tabular}{|c|c|c|c|c|}
\hline \multirow{2}{*}{$\begin{array}{l}\text { Addition } \\
\text { (glycan) }\end{array}$} & \multirow{2}{*}{$\begin{array}{c}\text { Weight ratio } \\
\text { (antibiotic: glycan) }\end{array}$} & \multirow{2}{*}{$\begin{array}{l}\text { Visible spectrum } \\
\qquad\left(\mathrm{H}_{2} \mathrm{O}\right)\end{array}$} & \multicolumn{2}{|c|}{$\begin{array}{c}\text { Specific rotation** } \\
\left([\alpha]_{\mathrm{p}}, \mathrm{H}_{2} \mathrm{O}\right)\end{array}$} \\
\hline & & & Found & Calcd. \\
\hline None (control) $)^{* * *}$ & & $500 \mathrm{~nm}$ & $+360^{\circ}$ & \\
\hline$\alpha-1,2-1,3-\operatorname{mannan}(\mathrm{A})$ & $1: 12$ & $515,565(\mathrm{sh}) \mathrm{nm}$ & $+372^{\circ}$ & $+102^{\circ}$ \\
\hline$\alpha-1,6-\operatorname{mannan}(1 \mathrm{~A}-5)$ & $1: 5$ & $515,565(\mathrm{sh}) \mathrm{nm}$ & $+784^{\circ}$ & $+152^{\circ}$ \\
\hline$\beta$-1,2-mannan (P) & $1: 4$ & $515,565(\mathrm{sh}) \mathrm{nm}$ & $+965^{\circ}$ & $+110^{\circ}$ \\
\hline Mannan (A) & $1: 5$ & $515,565(\mathrm{sh}) \mathrm{nm}$ & $+672^{\circ}$ & $+124^{\circ}$ \\
\hline D-Mannose & $1: 5$ & $500 \mathrm{~nm}$ & $+108^{\circ}$ & $+92^{\circ}$ \\
\hline Dextran $T-40$ & $1: 25$ & $500 \mathrm{~nm}$ & $+240^{\circ}$ & $+252^{\circ}$ \\
\hline
\end{tabular}

* An aqueous solution of glycan or sugar $(0.20 \sim 0.60 \%, \mathrm{w} / \mathrm{v})$ and benanomicin $\mathrm{A}(0.05 \%, \mathrm{w} / \mathrm{v})$ in weight ratios of $1: 4 \sim 1: 12 \mathrm{was}$ allowed to stand at room temperature for 5 minutes, and was subjected to measurement.

** Sum total of specific rotations of glycan or sugar and benanomicin A, provided that both values were additive.

*** An aqueous solution of benanomicin A alone. 
peak at $500 \mathrm{~nm}$ for benanomicin A was shifted to a longer wavelength with formation of a new shoulder at $565 \mathrm{~nm}$. The degree of red-shifting was dependent on the dose of yeast mannan. A maximum shift was observed at $515 \mathrm{~nm}$ at ratios of benanomicin A-mannan of $1: 5 \sim 1: 12$. Concurrent with these spectral changes, the optical rotations of a mixture of benanomicin A and yeast mannan, especially with the modified mannan $P$ containing $\beta$-1,2-linkage, were increased when compared with additive rotation values of the antibiotic and the yeast mannan.

When D-mannose or dextran T-40 was added to an aqueous solution of benanomicin $\mathrm{A}$, no shifting of the absorption maximum and no increase of optical rotation were observed under the conditions examined. Likewise, no change occurred when D-mannose, $\alpha$ - or $\beta$-cyclodextrin, dextran T-70, T-150, T-250, or amylose A was added to an aqueous solution of benanomicin A (data not shown). Benanomicinone which showed no binding to fungal cells did not cause significant spectral or rotational changes when mixed with yeast mannans (data not shown). These data indicate that benanomicin A binds specifically to yeast mannans irrespective of difference in the types of glycosidic linkages, but not to a monosaccharide D-mannose or D-glucose polymers.

\section{Discussion}

The present study demonstrate that benanomicin A binds to fungi and bacteria which are susceptible to the antibiotic when incubated in the presence of calcium ion. The antibiotic does not bind to bacterial and mammalian cells which are not inhibited by benanomicin $\mathrm{A}$. Furthermore, derivatives of benanomicins $\mathrm{A}$ and $\mathrm{B}$ (methyl ester and benanomicinone) without antifungal activity did not bind to any fungi or bacteria tested. Thus, it appears that the cell-binding ability of benanomicin A is closely associated with its biological activity leading to its selective toxicity against fungal cells. Both a carboxylic acid function of the D-alanine moiety and the sugar moiety with or without an amino group are essential for the binding ability of benanomicin A. The antibiotic appears to bind to the fungal cells tightly through hydrogen bonding, since only part of it was extracted with water while almost all the benanomicin A was recovered when DMSO, a strong cleaving agent of hydrogen bond, was used as the extraction solvent. The kinetics of benanomicin A binding is discussed in a separate paper. ${ }^{14)}$

Fungi susceptible to benanomicin A contain mannans or heteropolymeric mannans like galactomannan ( $A s$ pergillus), and susceptible bacteria also contain man- nans (Micrococcus lysodeikticus ${ }^{15)}$ ) and/or arabinomannans (Mycobacterium sp. ${ }^{16)}$ ). Therefore, the selective binding of benanomicin A to fungal cells leads us to the assumption that mannan or mannan-derived components of fungal cell walls might act as the receptor molecule for benanomicin A binding. This postulation is supported by the finding that benanomicin $\mathrm{A}$ was capable of binding to yeast mannans with several different glycosidic linkages, but not to any glucose polymers so far examined. It was also demonstrated that $\mathrm{Ca}^{2+}$ is again essential for benanomicin A binding to mannan, as was previously reported for pradimicins $^{17 \sim 21)}$ which are closely related to benanomicin $\mathrm{A}$ in chemical structure and biological activity ${ }^{22)}$.

Benanomicin A was demonstrated to be capable of binding not only to intact yeast cells but also to yeast protoplasts. It is known that mannan is also localized on yeast cell membranes as mannoproteins, although at a lower content than that found in yeast cell walls. On the basis of cell numbers, the amount of benanomicin $A$ or B bound to the protoplasts was almost equal to that of the intact cells, while the mannan content of yeast protoplasts was approximately $1 / 8$ that of intact yeast cells. This data suggest that benanomicin A binds to membrane-associated mannan or mannoproteins at a rate equal to or higher than that for cell wall mannans.

The ability of benanomicin A to bind selectively to yeast mannans appears similar to that of lectins. Concanavalin $\mathrm{A}$ is demonstrated to cause a change of fluidity of the cell membrane after binding to yeast cells. ${ }^{23)}$ In the context of interaction with $S$. cerevisiae, benanomicin $A$ and concanavalin $\mathrm{A}$ are similar in that they require $\mathrm{Ca}^{2+}$ for binding to yeast cells, and that they bind yeast cells to coagulate and to lyse the yeast protoplasts in the presence of Tween 80 . However, unlike benanomicin $\mathrm{A}$, concanavalin A binds to D-mannose, and is not lethal to whole yeast cells.

In conclusion, benanomicin A binds selectively to mannan or mannan-derived polysaccharide moieties localized on the cell envelope of fungi and other susceptible microorganisms. The carboxylic acid group, the sugar moiety and the chromophore of benanomicin $\mathrm{A}$ molecule are involved in the binding for which $\mathrm{Ca}^{2+}$ is essential. Although the binding to fungal cells is necessary for benanomicin $\mathrm{A}$ to exert an antifungal action, it remains unanswered how the antibiotic-binding becomes lethal. Current experiments are under way to determine the mechanism of this antifungal action.

\section{Acknowledgments}

The authors thank Dr. YoshinoRi Osumi, University of Tokyo for his kind supply of the yeast culture and helpful suggestions for this work, and Mr. SHorchi Amano, Pharmaceutical Research Center, Meiji Seika Kaisha, Ltd., for HPLC analysis. 


\section{References}

1) Takeuchi, T.; T. Hara, H. Naganawa, M. OKada, M. Hamada, H. Umezawa, S. Gomi, M. Sezaki \& S. Kondo: New antifungal antibiotics, benanomicins $\mathrm{A}$ and $\mathrm{B}$ from Actinomycetes. J. Antibiotics 41: $807 \sim 811,1988$

2) Matsuda, N.; M. OKada, M. Hamada \& K. HotTa: On the benanomicin producing strain MH 193-16F 4. Jap. J. Bacteriol. 46: 636, 1991

3) Gomi, S.; M. Sezaki, S. Kondo, T. Hara, H. Naganawa \& T. TAKeUCHI: The structures of new antifungal antibiotics benanomicins A and B. J. Antibiotics 41: 1019 1028,1988

4) Takeuchi, T.; T. Hara, M. Hamada, H. Yamamoto, S. Gomi, Y. Orikasa, M. Sezaki, S. Kondo \& H. YAMAGUCHI: Benanomicins $\mathrm{A}$ and $\mathrm{B}$, novel antifungal antibiotics. Program and Abstracts of the 28th Intersci. Conf. on Antimicrob. Agents Chemother., No. 1007, p. 288, Los Angeles, Oct. 23 26, 1988

5) Yamaguchi, H.; K. UChida, Y. Orikasa, T. Matsumoto, H. Yamamoto, S. Inouye, S. Kondo \& T. Takeuchi: Antifungal activity of benanomicin A, a novel antibiotic. Program and Abstracts of the 29th Intersci. Conf. on Antimicrob. Agents Chemother., No. 715, p. 1221, Houston, Sept. 17 20, 1989

6) Kondo, S.; D. Ikeda, M. Hamada, T. Takeuchi, H. Tohyama, H. Watabe, S. Gomi, S. Inouye \& $\mathrm{H}$. YAMAGUCHI: Structural requirement for antifungal action of benanomicin A (ME1451). Program and Abstracts of the 30th Intersci. Conf. on Antimicrob. Agents Chemothr., No. 589, P. 184, Atlanta, Oct. 23, 1990

7) Yamaguchi, M.; T. Hirata \& H. Yamaguchi: Mechanism of antifungal action of benanomicin A (ME1451). Program and Abstracts of the 30th Intersci. Conf. on Antimicrob. Agents Chemother. No. 590, p. 184, Atlanta, Oct. 23, 1990

8) Kondo, S.; S. Gomi, K. Uotani, S. Miyakawa, S. INOUYE, D. IKeDA \& T. TAKEUCHI: New hydroxybenanomicins produced by Actinomadura. Drugs Exptl. Clin. Res. 18: $217 \sim 224,1992$

9) Kondo, S.; S. Gomi, D. Ikeda, M. Hamada, T. Takeuchi, H. Hoshino \& J. Seki: Antifungal and antiviral activities of benanomicins and their analogues. J. Antibiotics 44: $1228 \sim 1236,1991$

10) Shibata, N.; K. Mizugami, K. Takano \& S. Suzuki: Isolation of mannan-protein complexes from viable cells of Saccharomyces cerevisiae X2180-1A wild type and Saccharomyces cerevisiae X2180-1A-5 mutant strains by the action of zymolyase-60,000. J. Bacteriol. 156: 552 558,1983

11) Kobayashi, H.; N. Shibata \& S. Suzuki: Acetolysis of Pichia pastoris IFO 0948 strain mannan containing $\alpha-1,2$ and $\alpha-1,3$ linkages using acetolysis medium of low sulfuric acid concentration. Arch. Biochem. Biophys. 245: $494 \sim 503,1986$

12) Tojo, M.; N. Shibata, M. Kobayashi, T. Mikami, M. SuzuKi \& S. Suzuki: Preparation of monoclonal antibodies reactive with $\alpha$-1,2-linked oligomannosyl residues in the phosphomannan-protein complex of Candida albicans NIH B-792 strain. Clin. Chem. 34: 539 543, 1988

13) Mikami, H. \& Y. Ishida: Post-column fluorometric detection of reducing sugars in high performance liquid chromatography using arginine. Bunseki Kagaku 32: E207 210, 1983

14) Taniguchi, M.; M. Aikawa \& T. Sakagami: Effect of prostaglandin E1 and polyphloretin phosphate on hemolysis of human erythrocytes. J. Biochem. (Tokyo) 91: $1173 \sim 1177,1982$

15) Watabe, H.; T. MikuniYa, S. Abe, H. Yamaguchi, Y. Yamamoto, T. Klein, H. Freedman, S. Kondo \& T. TAKEUCH: Antifungal antibiotic benanomicin A increases susceptibility of Candida albicans to phagocytosis by murine macrophages, J. Antibiotics, in preparation

16) OWEN P. \& M. R. J. SALton: A succinylated mannan in the membrane system of Micrococcus lysodeikticus, Biochem. Biophys. Res. Commun., 63: 875 880, 1975

17) Misaki, A.; I. Azuma \& Y. Yamamura: Structural and immunochemical studies on D-arabino-D-mannans and D-mannans of Mycobacterium tuberculosis and other Mycobacterium species. J. Biochem. (Tokyo) 82: 1759 1770,1977

18) Sawada, Y.; K. Numata, T. MuraKami, H. Tanimichi, S. YамAmoto \& T. OKr: Calcium-dependent anticandidial action of pradimicin A. J. Antibiotics 43: 715 721, 1990

19) Sawada, Y,; T. Murakami, T. Ueki, Y. Fukagawa, T. OKI \& Y. NozAWA: Mannan-mediated anticandicidal activity of BMY-28864, a new water-soluble pradimicin derivative. J. Antibiotics 44: 119 121, 1991

20) Ueki, T.; K. Numata, Y. Sawada, T. Nakajima, Y. FukaGawa \& T. OKI: Studies on the mode of antifungal action of pradimicin antibiotics. I. Lectin-mimic binding of BMY-28864 to yeast mannan in the presence of calcium. J. Antibiotics 46: 149 161, 1993

21) Ueki, T.; K. Numata, Y. Sawada, M. Nishio, H. Ohkuma, S. Toda, H. Kamachi, Y. Fukazawa \& $T$. OKI: Studies on the mode of antifungal action of pradimicin antibiotics. II. D-Mannopyranoside-binding site and calcium-binding site. J. Antibiotics 46: 455 464, 1993

22) UeKI, T.; M. OKa, Y. Fukazawa \& T. OKI: Studies on the mode of antifungal action of pradimicin antibiotics. III. Spectro-photometric sequence analysis of the ternary complex formation of BMY-28864 with D-mannopyranoside and calcium. J. Antibiotics 46: 465 477, 1993

23) Tsunakawa, M.; M. Nishino, H. Ohkuma, T. Tsuno, M. Konishi, T. Naito, T. OKI \& H. Kawaguchi: The structures of pradimicins A, B and C, a novel family of antifungal antibiotics. J. Org. Chem. 54: $2532 \sim 2536$, 1989

24) Goldstein, I. J. \& C. E. Hayes: Lectins. Adv. Carbohydrate Chem. Biochem. 35: 150 190, 1978 